Dataset Paper

\title{
Reproductive Dynamics of Iheringichthys labrosus (Lütken, 1874) (Teleostei, Pimelodidae), in the Capivara Reservoir, Paranapanema River, Parana, Brazil
}

\author{
Fábio Mineo Suzuki, ${ }^{1}$ Diego Azevedo Zoccal Garcia, ${ }^{2}$ and Mário Luís Orsi ${ }^{2}$ \\ ${ }^{1}$ Grupo de Pesquisa em Ecologia e Revitalização de Ambientes Aquáticos, Departamento de Biologia, Setor de Ecologia, \\ Universidade Federal de Lavras, Campus Universitário, Caixa Postal 3037, 37200-000 Lavras, MG, Brazil \\ ${ }^{2}$ Departamento de Biologia Animal e Vegetal, Centro de Ciências Biológicas, Universidade Estadual de Londrina, \\ Campus Universitário, Caixa Postal 6001, 86051-990 Londrina, PR, Brazil
}

Correspondence should be addressed to Mário Luís Orsi; orsi@uel.br

Received 22 March 2012; Accepted 17 April 2012

Academic Editors: S. Fenoglio and P. Tryjanowski

Copyright (C) 2013 Fábio Mineo Suzuki et al. This is an open access article distributed under the Creative Commons Attribution License, which permits unrestricted use, distribution, and reproduction in any medium, provided the original work is properly cited.

To study the reproductive dynamics of the mandi-beiçudo, Iheringichthys labrosus, in the Capivara Reservoir, Paranapanema River, Parana, Brazil, specimens were captured trimonthly from March 2001 to July 2004 at four sampling sites. The sex ratio showed a predominance of females in most of months sampled and the larger length classes. The majority of the individuals captured showed a standard length between 16 and $22 \mathrm{~cm}$, with a maximal length of $27.5 \mathrm{~cm}$. The size at first maturity was estimated to be 18.1 and $19.7 \mathrm{~cm}$ for females and males, respectively. Analysis of the temporal variation of the gonadosomatic index (GSI) and frequency of occurrence of gonadal maturation stages of males and females for the months sampled showed that I. labrosus reproduces during the whole year, with peak reproduction in November and December. There was a positive correlation between the mean values of GSI and variation in rainfall values, suggesting that this abiotic factor can influence the reproduction of this species. The mean absolute fecundity was $67274.5 \pm 16562.5$ oocytes, and the mean relative fecundity was $350.6 \pm 186.3$ oocytes per gram of total weight.

\section{Introduction}

The order Siluriformes represents a group that is widely distributed and one of the most diverse among the Ostariophysi, comprising about 34 families, 412 genera, and more than 2400 species [1]. Among the families, the family Pimelodidae should be noted as one of the largest and most diverse in freshwater environments, containing more than 300 species of fishes [2].

The pimelodid Iheringichthys labrosus, known as the mandi-beiçudo, is considered a small- to medium-sized species [3-6] with a bentophagous habit [7-10]. The species has a wide geographic distribution [2], where it is one of the most dominant in Brazilian reservoirs, mainly in the Parana River basin [11]. Although it is considered an important catch in commercial fishing, there are few studies about its biology.
Noteworthy among these are the recent works conducted by Santos et al. [12] and Holzbach et al. [13].

Vazzoler [3] and Wooton [14] pointed out that studies about the reproductive process are important, because the success obtained by any species is determined by the capacity of its members to reproduce in a variable environment, maintaining viable populations as a basis for mechanisms of stock maintenance. Because of this and the lack of information on the reproductive biology of this species, the aim of this study was to evaluate the characteristics of the reproductive dynamics of I. labrosus in the reservoir of the UHE Escola de Engenharia Mackenzie-Capivara Reservoir, by the determination of sex ratio, length at first gonadal maturation, reproductive period, type of spawning, and fecundity. 


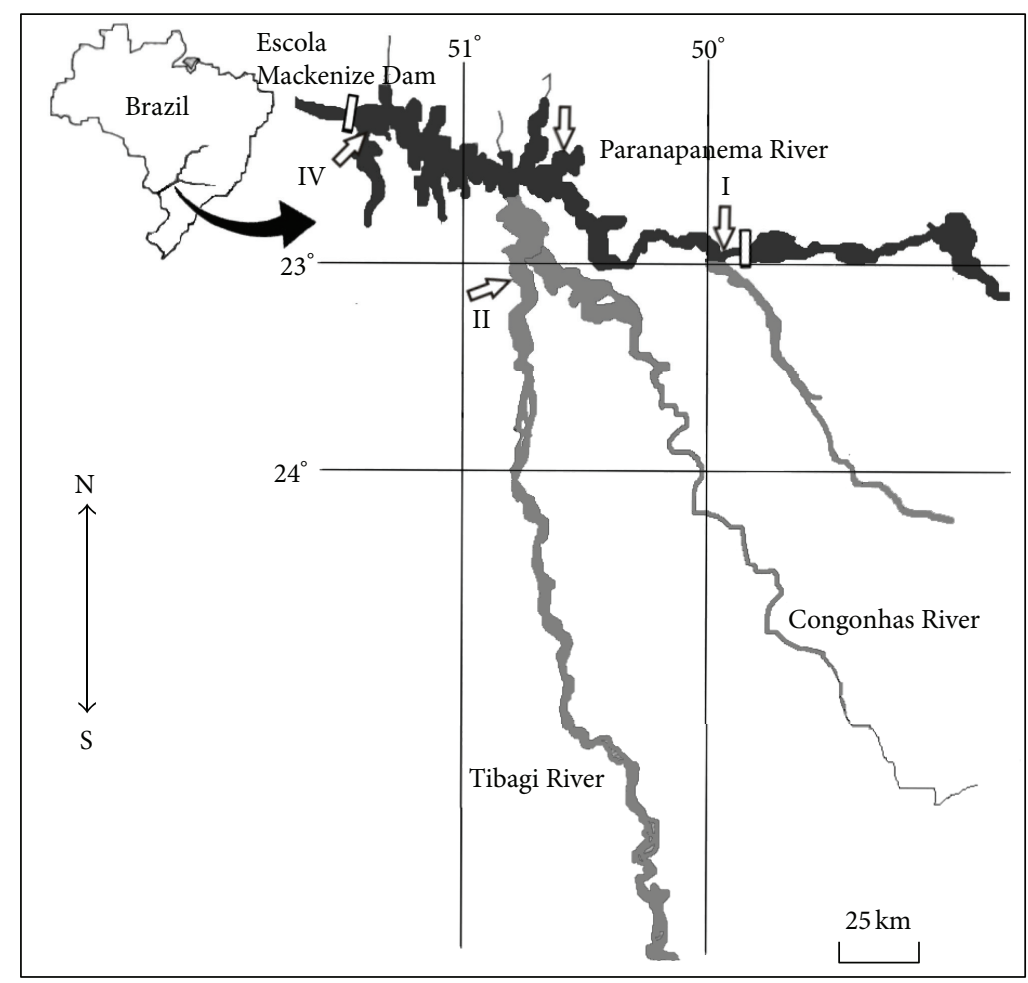

Figure 1: Map of the hydrographic basin of the Paranapanema River (scale 1:15000), in the area of the Capivara Reservoir in which are located the four sampling stretches: I-Cinzas, II-Sertanopolis, III-Cruzalia, and IV-Porecatu.

\section{Methodology}

This study was carried out in the Capivara Reservoir of UHE Escola de Engenharia Mackenzie, located in the Paranapanema River basin, constructed in the confluence of the original bed of the Paranapanema River with the bed of the Vermelho River, in the northeastern region of the state of Parana and southeastern part of the state of São Paulo [15]. Its drainage area is $85,000 \mathrm{~km}^{2}$, while its established potential is $640 \mathrm{MW}$ annually, which makes it the largest and most efficient in energy production among the 10 hydroelectric plants in operation on this river [16]. Its banks are occupied by pastures and agricultural fields, and a few forest fragments occur close to the mouth of the Tibagi River [17].

The collections were made trimonthly, in the period from March 2001 to July 2004 at four sampling sites, from upstream to downstream, designated Cinzas $\left(22^{\circ} 51^{\prime} 52^{\prime \prime} \mathrm{S}\right.$, $\left.50^{\circ} 53^{\prime} 56^{\prime \prime} \mathrm{W}\right)$, Cruzalia $\left(22^{\circ} 46^{\prime} 14^{\prime \prime} \mathrm{S}, \quad 50^{\circ} 50^{\prime} 34^{\prime \prime} \mathrm{W}\right)$, Sertanopolis $\left(23^{\circ} 01^{\prime} 16^{\prime \prime} \mathrm{S}, 50^{\circ} 57^{\prime} 13^{\prime \prime} \mathrm{W}\right)$, and Porecatu $\left(22^{\circ} 58^{\prime} 09^{\prime \prime} \mathrm{S}, 51^{\circ} 33^{\prime} 24^{\prime \prime} \mathrm{W}\right)$, with the objective of encompassing the whole reservoir (Figure 1).

The specimens were caught with gill nets with meshes of 1 to $10 \mathrm{~cm}$ between opposite knots, covering on average $1824 \mathrm{~m}^{2}$ of area at each of the stretches. The nets were placed in both the marginal zone and deep areas in the river channel, parallel and perpendicular to the bank. The capture effort was standardized in 24-hour periods, with two inspections of the nets, at dawn and at dusk. Sieves and multifilament drag nets with mesh size of $0.5 \mathrm{~cm}\left(85 \mathrm{~m}^{2}\right)$ were used for two hours of effort to complement the sampling.

The fish captured were anesthetized with benzocaine to death and then fixed in the field in $10 \%$ formalin and taken to the laboratory for identification of the specimens collected, according to Shibatta et al. [4]. Later, biometry, sex identification, and determination of stage of gonadal maturation were carried out.

Based on macroscopic analyses of transparency, coloration, superficial vascularization, turgidity, volume occupied in the abdominal cavity, and visible oocytes (in the case of females), the gonads were classified according to the gonadal maturation scale of Marcucci et al. [17]. This scale consisted of the following stages: immature (I), maturing (II), mature or partially spent (III), and spent and resting (IV). The macroscopic stages of maturation were validated by the histological preparation of slides of gonads and examination using the classic method of hematoxylin-eosin staining.

The sex ratio was determined by the number of individuals collected per month sampled and per standard length (SL) class and tested according to the $\chi^{2}$ test (5\% level of significance) to determine significant differences. The standard length class was established by the formula of Sturges [18]. The sex ratio was evaluated only for adults, since it was not possible to determine the sex of juveniles because of their immature gonads.

The length at first gonadal maturation (LFGM) was obtained by the standard length of the smallest individual in 


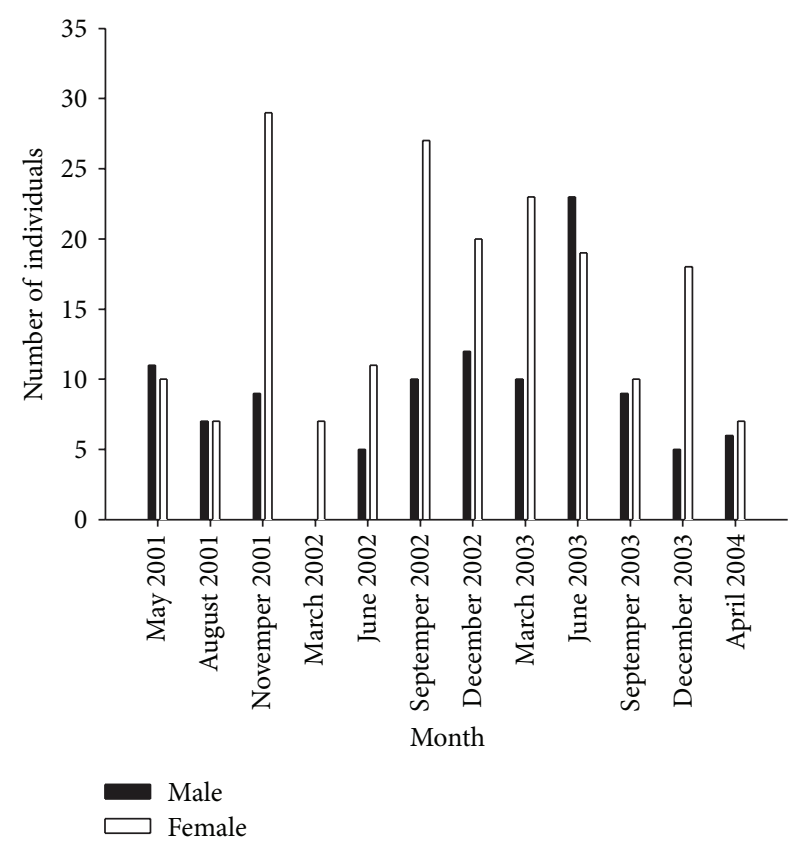

(a)

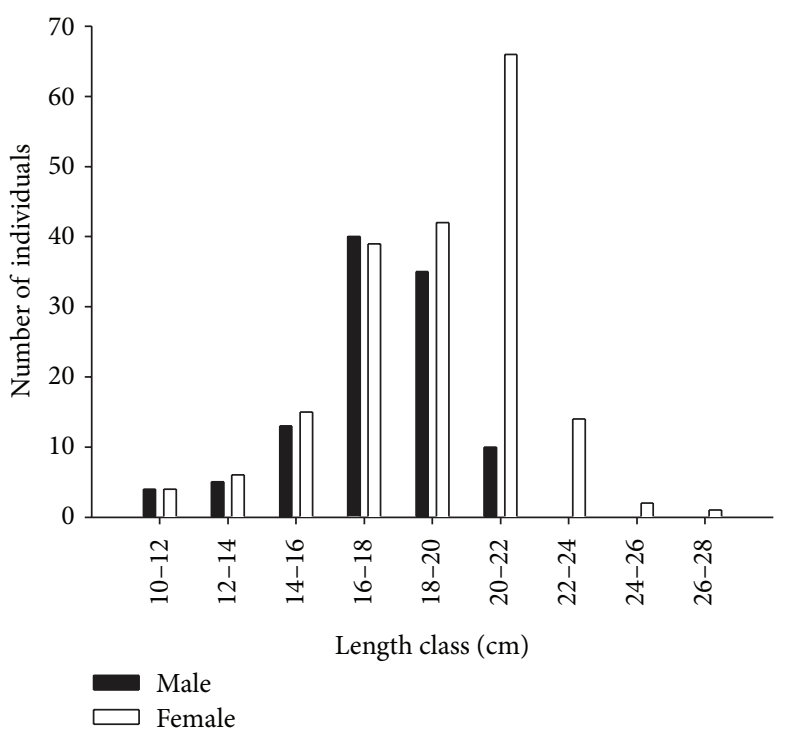

(b)

FIGURE 2: Number of male and female individuals per sampling month (a) and per standard length class (b) for specimens of $I$. labrosus in the Capivara Reservoir, Paranapanema River, from March 2001 to July 2004.

reproduction (advanced process of gonadal maturation), as suggested by Sato and Godinho [19].

The reproductive period was determined for males and females separately by analysis of the mean variation of values of the gonadosomatic index (GSI) [3]. The mean monthly precipitation levels during the study period were correlated with the mean GSI of males and females by linear regression. Mean rainfall levels of the months sample were obtained from the operations center of Duke Energy International Geração Paranapanema.

Absolute fecundity was estimated for females based on the total number of mature oocytes, while relative fecundity was the ratio of number of mature oocytes to the total weight.

A total of 295 individuals of the species I. labrosus were captured during the study period, of which $98.7 \%$ were adults and $1.3 \%$ juveniles. There was a predominance of females captured in relation to males in the majority of months sampled, with a sex ratio for the total number of individuals captured significantly differing from $1: 1\left(\chi^{2}=22.72, \mathrm{df}=1\right.$, $P<0.05)$.

About $77.3 \%$ of the total individuals captured showed an SL between 16.0 and $22.0 \mathrm{~cm}$, with a mean of $18.4 \pm 2.75 \mathrm{~cm}$. However, there was a predominance of females in the larger SL classes, where this difference was significant as of class 20.0 to $22.0 \mathrm{~cm}\left(\chi^{2}=54.76, \mathrm{df}=1, P<0.05\right)$ and only the presence of females as of class 22.0 to $24.0 \mathrm{~cm}$ (Figure 2). The largest individual captured had an SL of $27.5 \mathrm{~cm}$.

Differences in LFGM were observed between the sexes, where this length in the females was smaller in relation to the males, 18.1 and $19.7 \mathrm{~cm}$, respectively.
The temporal variation of GSI means for both sexes revealed greater reproductive activity in the months of November and December, accompanied by the variation in rainfall (Figure 3). The high correlation between these two variables for males $\left(r^{2}=0.59 ; P<0.0057\right)$ and females $\left(r^{2}=0.83 ; P<0.00003\right)$ suggests a strong influence of this environmental factor on the reproductive seasonality of this species.

The frequencies of occurrence of stages of gonadal maturation for males and females of I. labrosus showed the distribution of stages III and IV, in practically the entire period studied, indicating reproductive activity during the whole year. The highest frequencies of occurrence for stage III in both sexes were observed between November and March followed by an increase in frequency of individuals in stage IV in the following period (Figure 4).

The mean absolute and relative fecundity found was $67,274.5 \pm 16,562.5$ oocytes and $350.6 \pm 186.3$ oocytes per gram of total weight of female, respectively. The mean diameter of the mature oocytes was about 0.42 to $0.49 \mathrm{~mm}$, where the maximal diameter was $0.70 \mathrm{~mm}$.

According to Nikolsky [20], the classic sex ratio among fishes is $1: 1$, although differences from this proportion can be found. Nikolsky [21] considered that this variation in sex ratio among populations of the same species can be due to adaptation that assures the predominance of females when the conditions are very favorable for egg production, such as during the colonization of a new environment or when the species suffers from intensive fishing. For I. labrosus, this variation is probably related to intensive fishing, which has plagued this species, as noted by Duke Energy [6]. 


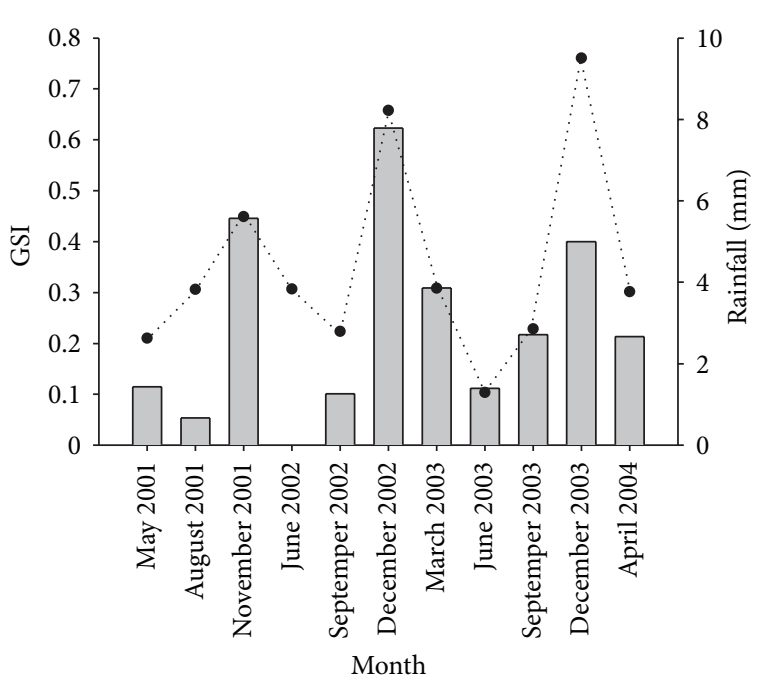

(a)

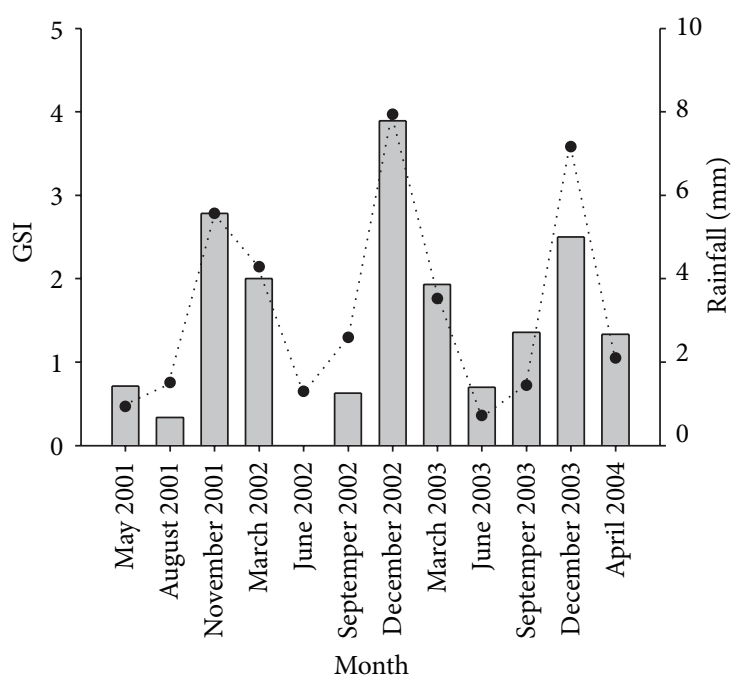

(b)

FIgURE 3: Mean gonadosomatic index of males (a) and females (b) per sampling month for specimens of I. labrosus and temporal variation of mean rainfall in the Capivara Reservoir, River Paranapanema, from March 2001 to July 2004.

The capture of individual males and females in various classes of length suggests the coexistence of various age groups, in space and time, which can be an indication that these environments have conditions favorable to their development, as affirmed by Orsi et al. [22]. The majority of individuals captured showed a standard length between 16.0 and $22.0 \mathrm{~cm}$, with a mean of $18.4 \pm 2.75 \mathrm{~cm}$, greater than that recorded by Holzbach et al. [13]. However, these authors recorded a maximal size $(28.5 \mathrm{~cm})$ greater than that found in the present study $(27.5 \mathrm{~cm})$.

The significant predominance of females in the class 20.0 to $22.0 \mathrm{~cm}$ and the presence of only females in the larger classes denote that they grow faster than the males, as previously observed by Orsi et al. [5] in the Tibagi River. This result corroborates that of Vazzoler [3], where in this type of analysis, there is generally a predominance of females in the larger length classes, because they have faster growth rates than males and, consequently, attain superior lengths for the same age. Nikolsky [21] reported that the male tends to be larger in species that defend the progeny, which is not the case with this species, as there is no evidence of any pattern of parental care.

The low capture rate of young specimens possibly indicates that the young individuals may be living in different environments compared to adults, as previously suggested by Lowe-McConnell [23]. However, this hypothesis cannot be discarded since the captures were restricted to a few stretches of the reservoir if considering the size of the reservoir.

The determination of LFGM represents an important information for the purpose of implementing regulatory measures in fishing and helps define the minimal size for the capture of individuals [24]. This parameter is a very flexible reproductive tactic, because it is intimately related to growth, showing intraspecific, spatial, and temporal variations related to abiotic and biotic environmental conditions prevalent in the region occupied in the period, to which the population is submitted [3]. This possibly explains the variations found in LFGM between the sexes in this study, which denotes the precocity in the maturation of females, since they showed a lower LFGM in relation to the opposite sex.

The analysis of reproductive activity by period reveals that this occurred more intensely in November and December, where this finding is in agreement with the results of Holzbach et al. [13] and similar to the results obtained by Santos et al. [12]. It is noteworthy that the reproductive period accompanied the months with greatest rainfall. According to Lowe-McConnell [25], the teleost fishes of tropical regions show a strict relation between reproductive activity and the rainy period. This is probably an environmental factor for the initiation of spawning in this species. However, this relation needs to be better investigated since rainfall can show interactions with other abiotic factors. It should be noted that accumulation reservoirs, like in this study, show large variations in water level, which can also influence reproduction.

The high number of individuals in stage III between November and December, according to the frequencies of occurrences of stages of gonadal maturation for the specimens of I. labrosus, confirms the results of variation in GSI values, indicating the intense reproductive activity in this period. The presence of individuals in stages III and IV in the other seasons demonstrates reproductive activity, albeit incipient, outside of spring, showing that reproduction occurs during the whole year. This characteristic can be important 


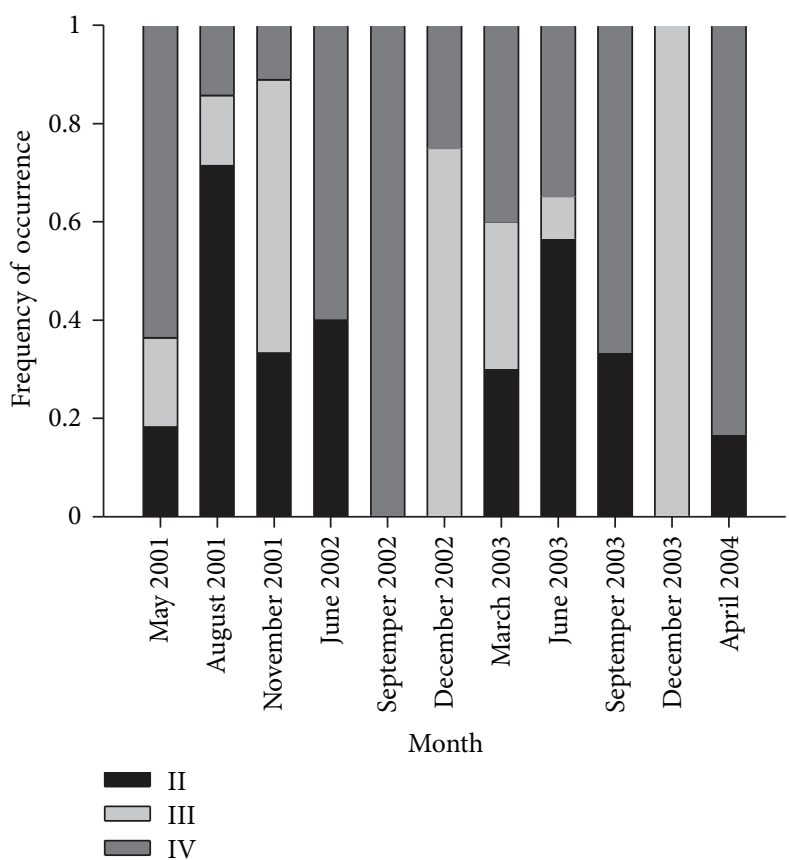

(a)

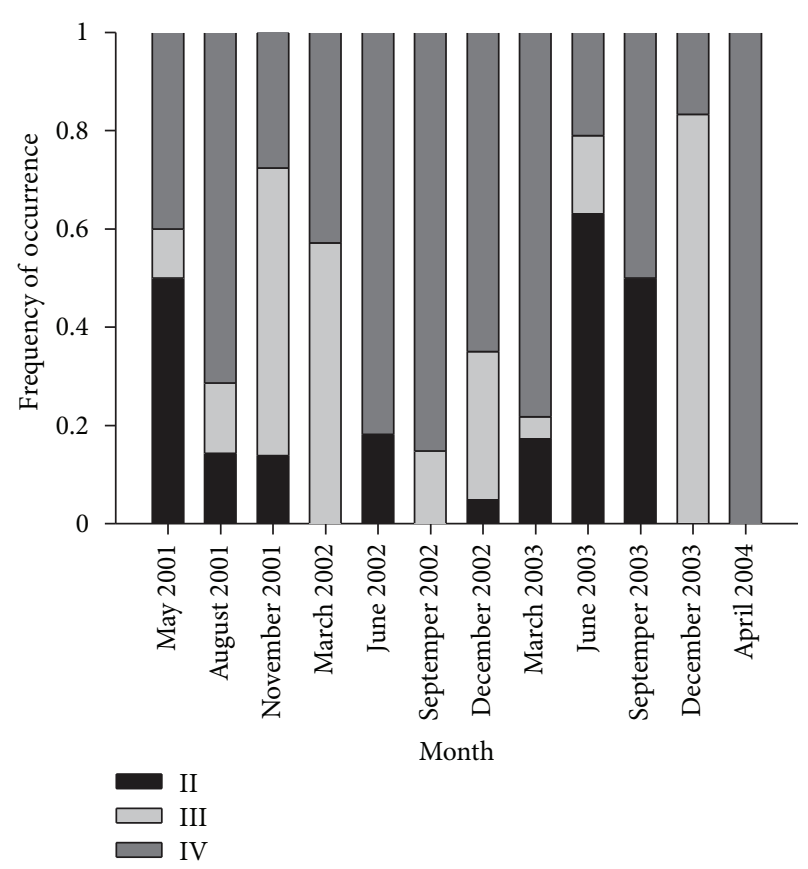

(b)

FIGURE 4: Frequencies of occurrence of gonadal maturation stages of males (a) and females (b) for specimens of I. labrosus in the Capivara Reservoir, River Paranapanema, from March 2001 to July 2004.

and advantageous for the species, because it possibly allows the asynchronous development of larvae, where this is an efficacious strategy to avoid competition between spawning location and food for larvae [21], which increases the chances of perpetuation of the species [26].

The evaluation of fecundity was an important help in estimating fish stocks and production of fry in fish farming, besides providing indications of life strategy of species [24]. According to Agostinho and Júlio Jr. [27], the species I. labrosus tends to have a high fecundity with a smaller egg diameter. However, when compared to the relative fecundity of the species Pimelodus maculatus La Cepède 1803, belonging to the same family, this value appears to be minor than that reported by Maia et al. [28], revealing a low fecundity compared to $P$. maculatus, which can be an advantage in detriment to the reproductive behavior of nonmigratory species.

\section{Dataset Description}

The dataset associated with this Dataset Paper consists of one item which is described as follows.

Dataset Item 1 (Table). A total of 295 individuals of the species I. labrosus were captured during the study period, of which $98.7 \%$ were adults and $1.3 \%$ juveniles.

Column 1: NI

Column 2: Total Length $(\mathrm{cm})$

Column 3: Standard Length $(\mathrm{cm})$

Column 4: Total Weight (g)
Column 5: Sex

Column 6: Maturity Stage

Column 7: Gonad Weight (g)

Column 8: Season

Column 9: Location

Column 10: Date

Column 11: RGS

Column 12: Mean Rainfall (mm)

\section{Concluding Remarks}

The results of this work indicate that the females of I. labrosus predominated in the majority of months sampled and in the larger length classes. There was precocity in the maturation of females in relation to males, and the species displayed reproductive activity during the entire year with peaks of reproduction in November and December, accompanying the variation in rainfall. Therefore, we can infer that even with the various impacts of river damming, this fish is still able to develop to maintain its populations relatively viable in the system. We conclude that I. labrosus is a resident of the Capivara Reservoir and completes its life cycle in this type of environment.

\section{Dataset Availability}

The dataset associated with this Dataset Paper is dedicated to the public domain using the CCO waiver and is available at http://dx.doi.org/10.7167/2013/607541/dataset. 


\section{Acknowledgments}

The authors thank the technicians Edson Santana da Silva and Aparecido de Souza of the Museum of Zoology at the Universidade Estadual de Londrina for the great help in the field work and laboratory. They are grateful to Dr. Oscar Akio Shibatta for his helpful suggestions. Universidade Estadual de Londrina and Duke Energy International provided financial support. Dr. A. Leyva helped with the translation and editing of the paper.

\section{References}

[1] J. S. Nelson, Fishes of the World, John Wiley \& Sons, New York, NY, USA, 1994.

[2] W. E. Burgess, An Atlas of Freshwater and Marines Catfishes: A Preliminary Survey of the Siluriformes, T. F. H., New Jersey, NJ, USA, 1989.

[3] A. E. A. M. Vazzoler, Biologia da Reprodução de Peixes Teleósteos: Teoria e Prática, EDUEM, Maringá, Brazil, 1996.

[4] O. A. Shibatta, M. L. Orsi, S. T. Bennemann, and Â. T. SilvaSouza, "Diversidade e distribuição de peixes na bacia do rio Tibagi," in A Bacia do rio Tibagi, M. E. Medri, E. Bianchini, O. A. Shibatta, and J. A. Pimenta, Eds., pp. 403-424, Londrina, Brazil, Universidade Estadual de Londrina, 2002.

[5] M. L. Orsi, O. A. Shibatta, and Â. T. Silva-Souza, "Caracterização biológica de populações de peixes do rio Tibagi, localidade de Sertanópolis," in A Bacia do rio Tibagi, M. E. Medri, E. Bianchini, O. A. Shibatta, and J. A. Pimenta, Eds., pp. 425-432, Londrina, Brazil, Universidade Estadual de Londrina, 2002.

[6] Duke Energy International Geração Paranapanema, Reservatório da UHE Escola Mackenzie, Duke Energy, Caracterização dos Pescadores do Reservatório de Capivara-Rio Paranapanema. São Paulo, Brazil, 2003.

[7] N. S. Hahn, I. F. Andrian, R. Fugi, and V. L. L. Almeida, "Ecologia trófica," in A Planície de Inundação do alto rio Paraná: Aspectos Físicos, Biológicos e Socioeconômicos, A. E. A. M. Vazzoler, A. A. N. S. HAHN Agostinho, and N. S. HAHN, Eds., EDUEM, Maringá, Brazil, 1997.

[8] S. D. S. Abes, A. A. Agostinho, E. K. Okada, and L. C. Gomes, "Diet of Iheringichthys labrosus (Pimelodidae, Siluriformes) in the Itaipu Reservoir, Parana River, Brazil-Paraguay," Brazilian Archives of Biology and Technology, vol. 44, no. 1, pp. 101-105, 2001.

[9] S. T. Bennemann and O. A. O. A. Shibatta, "Dinâmica de uma assembléia de peixes do rio Tibagi," in A Bacia do rio Tibagi, M. E. Medri, E. Bianchini, O. A. Shibatta, and J. A. Pimenta, Eds., pp. 433-442, Universidade Estadual de Londrina, 2002.

[10] C. K. Fagundes, E. R. Behr, and C. B. Kotzian, "Diet of Iheringichthys labrosus (Siluriformes, Pimelodidae) in the Ibicuí River, Southern Brazil," Iheringia, vol. 98, no. 1, pp. 60-65, 2008.

[11] A. A. Agostinho, L. C. Gomes, and F. M. Pelicice, Ecologia e Manejo de Recursos Pesqueiros em Reservatórios do Brasil, EDUEM, Maringá, Brazil, 2007.

[12] J. E. Santos, N. Bazzoli, E. Rizzo, and G. B. Santos, "Reproduction of the catfish Iheringichthys labrosus (Lütken) (Pisces, Siluriformes) in Furnas Reservoir, Minas Gerais, Brazil," Revista Brasileira de Zoologia, vol. 21, no. 2, pp. 193-200, 2004.

[13] A. J. Holzbach, E. A. Gubiani, and G. Baumgartner, "Iheringichthys labrosus (Siluriformes: Pimelodidae) in the Piquiri River, Paraná, Brazil: population structure and some aspects of its reproductive biology," Neotropical Ichthyology, vol. 7, no. 1, pp. 55-64, 2009.

[14] J. R. Wooton, Ecology of Teleost Fishes, Kluwer Academic/ Plenum, New York, NY, USA, 2nd edition, 1998.

[15] E. D. Carvalho, S. G. Britto, and M. L. Orsi, "O panorama das introduções de peixes na bacia hidrográfica do rio Paranapanema, alto Paraná, Brasil," in Espécies Invasoras em Águas Doces: Estudos de Caso e Propostas de Manejo, O. Rocha, E. L. G. Espíndola, N. Fenerich-Verani, J. R. Verani, and A. C. Rietzler, Eds., p. 416, UFSC, São Carlos, Brazil, 2005.

[16] Duke Energy International Geração Paranapanema, Peixes do rio Paranapanema, Horizonte Geográfico, São Paulo, Brazil, 2003.

[17] K. M. I. Marcucci, M. L. Orsi, and O. A. Shibatta, "Abundância e aspectos reprodutivos de Loricariichthys platymetopon (Siluriformes, Loricariidae) em quatro trechos da represa Capivara, médio rio Paranapanema," Iheringia, vol. 95, no. 2, pp. 197-203, 2005.

[18] M. Ayres, M. Ayres Jr., D. L. Ayres, and A. A. Santos, Biostat 5.0: Aplicações Estatística nas Áreas das Ciências Biológicas e Médicas, Sociedade Civil Mamirauá, Belém, Brazil, 2007.

[19] Y. Sato and H. P. Godinho, "A questão do tamanho da primeira maturação dos peixes de Três Marias, MG," in Coletânea de Resumos do Encontro da Associação Mineira de Aquicultura, Codevasf, Brasília, Brazil, 1988.

[20] G. V. Nikolsky, Theory of Fish Population Dynamic, Oliver \& Boyd, Edinburgh, UK, 1969.

[21] G. V. Nikolsky, The Ecology of Fishes, Academic Press, New York, NY, USA, 1963.

[22] M. L. Orsi, E. D. Carvalho, and F. Foresti, "Biologia populacional de Astyanax altiparanae Garutti \& Britski (Teleostei, Characidae) do médio rio Paranapanema, Paraná, Brasil," Revista Brasileira de Zoologia, vol. 21, no. 2, pp. 207-218, 2004.

[23] R. H. Lowe-McConnell, Estudos Ecológicos de Comunidades de Peixes Tropicais, EDUSP, São Paulo, Brazil, 1999.

[24] W. Bruschi Junior, A. Carvalho Peret, J. R. Varani, and C. Bernhardt Fialho, "Reproduction of Loricariichthys anus (Valenciennes, 1840) from Emboaba Lake, Osorio City, RS, Brazil," Revista Brasileira de Biologia, vol. 57, no. 4, pp. 677-685, 1997.

[25] R. H. Lowe-McConnell, Fish Communities in Tropical Freshwaters, Longman, New York, NY, USA, 1975.

[26] A. M. L. Veregue and M. L. Orsi, "Biologia reprodutiva de Astyanax scabripinnis paranae (Eigenmann) (Osteichthyes, Characidae), do ribeirão das Marrecas, bacia do rio Tibagi, Paraná," Revista Brasileira de Zoologia, vol. 20, no. 1, pp. 97-105, 2003.

[27] A. A. Agostinho and H. F. Júlio Jr., "Peixes da bacia do alto Paraná," in Estudos Ecológicos de Comunidades de Peixes Tropicais, R. H. Lowe-McConnell, Ed., EDUSP, São Paulo, Brazil, 1999.

[28] B. P. Maia, S. M. F. Ribeiro, P. M. Bizzotto, V. Vono, and H. P. Godinho, "Reproductive activity and recruitment of the yellow-mandi Pimelodus maculatus (Teleostei: Pimelodidae) in the Igarapava Reservoir, Grande River, Southeast Brazil," Neotropical Ichthyology, vol. 5, no. 2, pp. 147-152, 2007. 

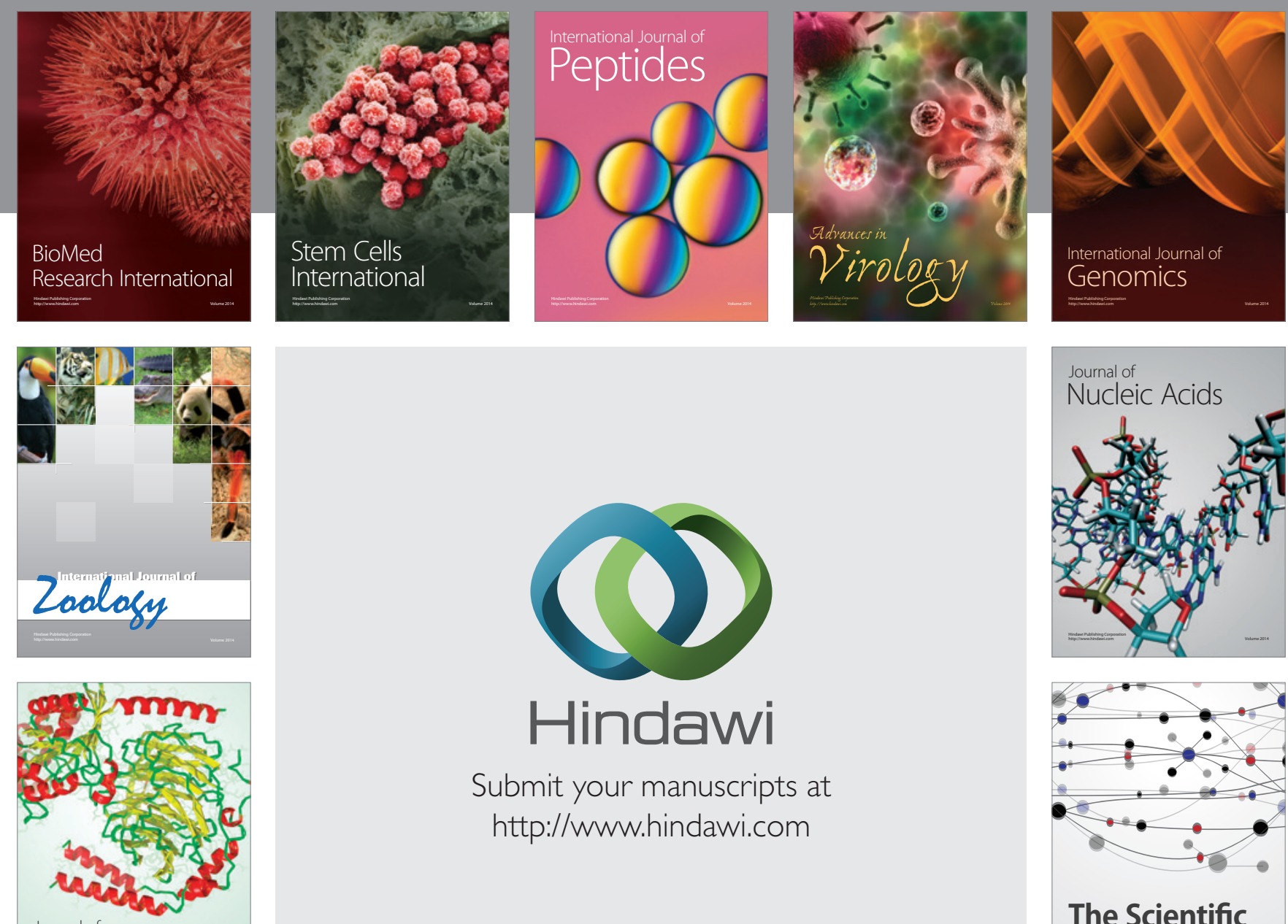

Submit your manuscripts at

http://www.hindawi.com

Journal of
Signal Transduction
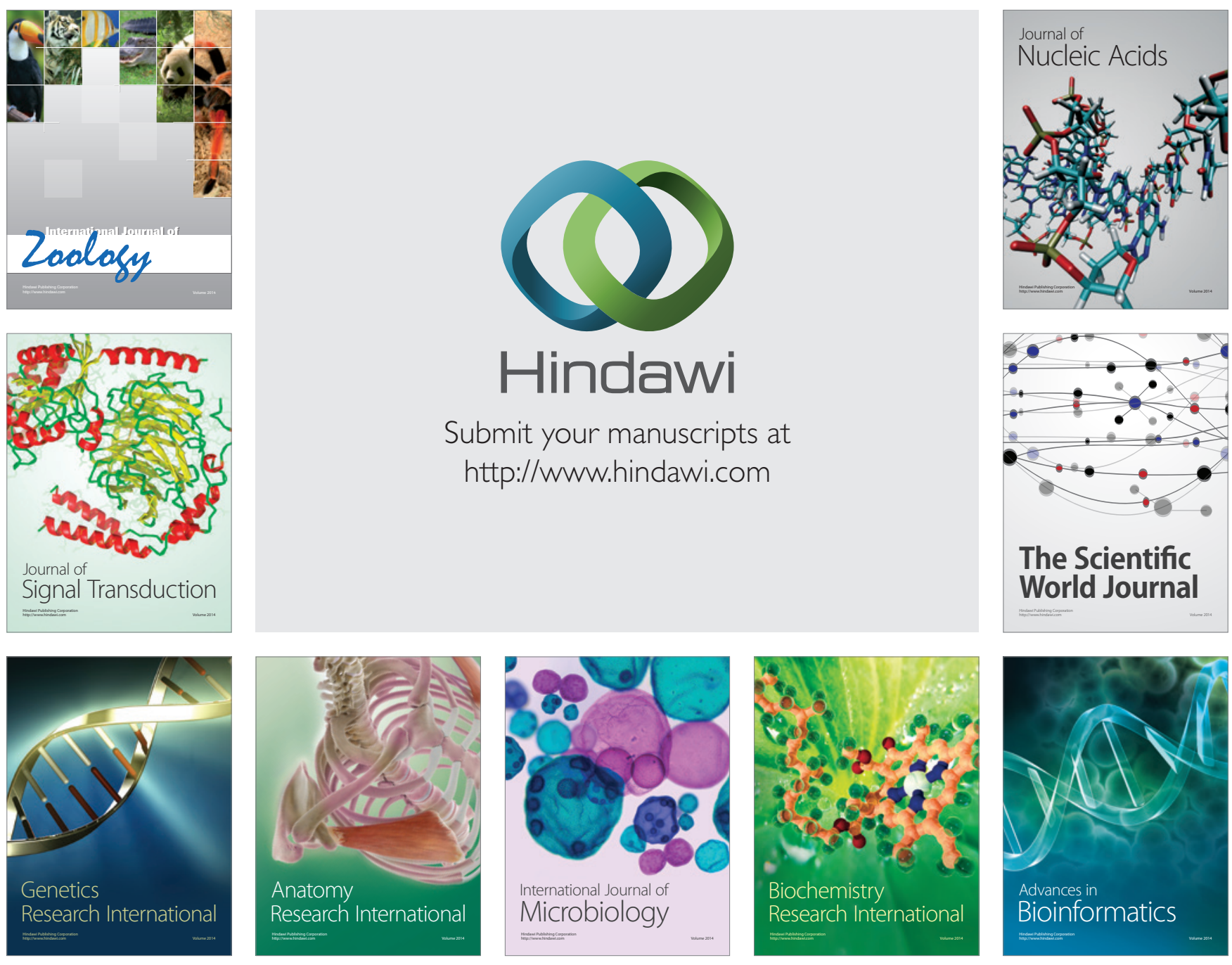

The Scientific World Journal
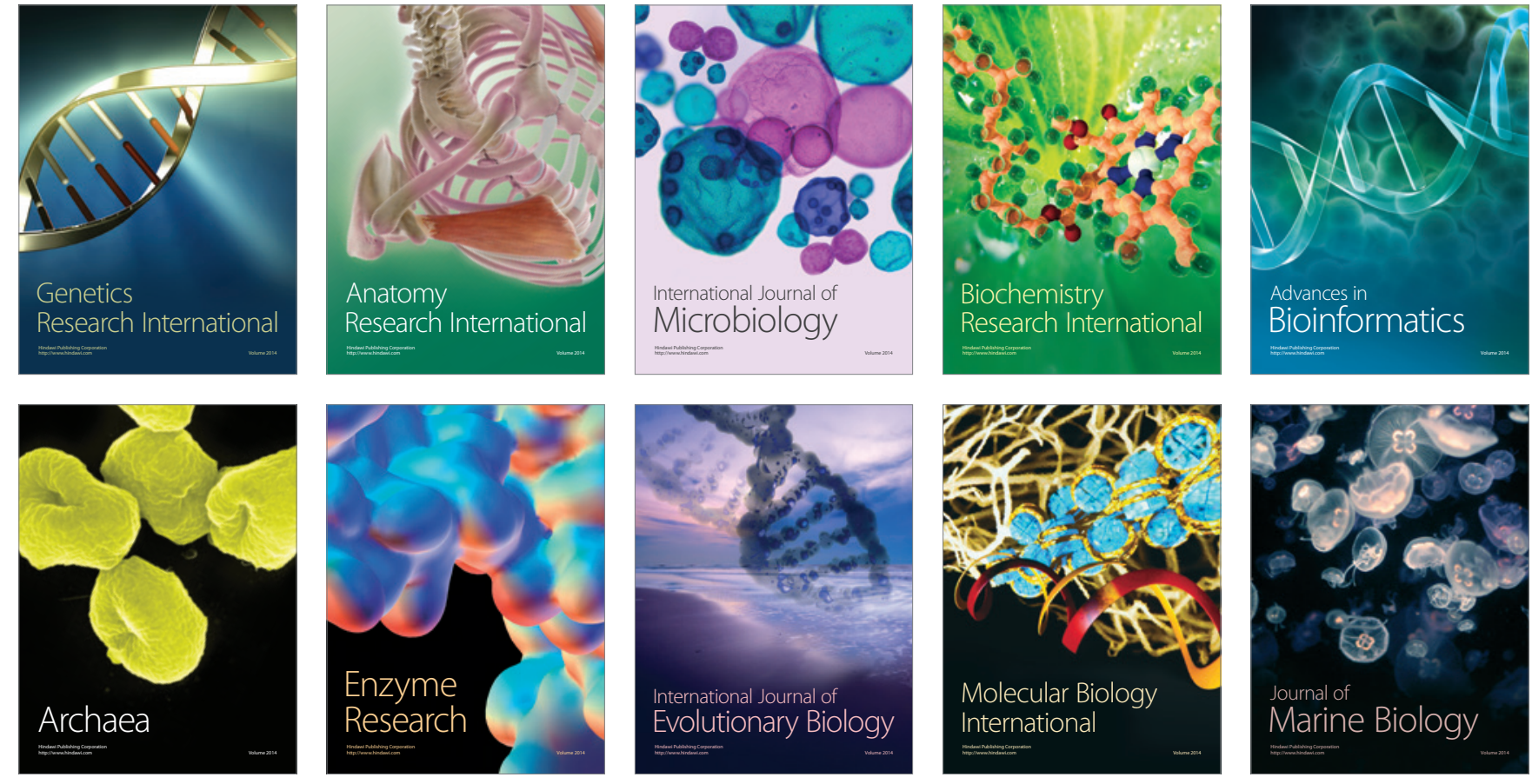